\title{
STANDARD ISO 9001:2015, MOST IMPORTANT CHANGES AND THEIR IMPACT ON SUPPLIER COMPLAINTS MANAGEMENT
}

\author{
Adela Melicharova \\ Czech University of Life Sciences Prague, Czech Republic \\ melicharovaa@tf.czu.cz
}

\begin{abstract}
ISO 9001 is the international standard that specifies requirements for a quality management system (QMS). The latest version is ISO 9001:2015. Organizations that are currently registered to ISO 9001:2008 will have until September 2018 to pass over to the 2015 standard. The paper attempts to provide knowledge on the most important changes from ISO 9001:2008 to ISO 9001:2015 and their impact on supplier complaints management in organizations. One of the most significant changes in ISO 9001:2015 versus ISO 9001:2008 is the increased focus on risk-based thinking in requirements for planning, review and improvement of the QMS and its processes. This also applies to manage suppliers. The aim of this paper is to: (i) analyse the supplier claims in organization, (ii) identify the most problematic category of supplied products, and (iii) determine riskbased requirements for suppliers of this category with regard to the ISO 9001:2015. For this purpose, organization XY was used as the case study. XY is located in the Czech Republic and is the molded plastic parts producer, including their decoration, assembling and final packaging process.
\end{abstract}

Keywords: QMS, ISO 9001:2015, complaint, supplier, costs.

\section{Introduction}

ISO 9001 is an International Standard of the Quality Management System (QMS). ISO 9001 specifies the basic requirements for a quality management system that an organization must fulfil to demonstrate its ability to consistently provide products and services that enhance customer satisfaction and meet applicable statutory and regulatory requirements [1]. This International Standard is based on the quality management principles described in ISO 9000 [2].

ISO 9001 has been revised several times. The first version was published in 1987. ISO 9001 underwent revisions in 1994, 2000 and again in 2008. The latest revision was published in September 2015 and is known as ISO 9001:2015 [3]. This fifth edition cancels and replaces the fourth edition (ISO 9001:2008) [2]. Organizations that are currently registered to ISO 9001:2008 will have until September 2018 to pass over to the 2015 standard [3].

In 1993, when a system overview of certifications was for the first time introduced, 24000 certificates were registered in 48 countries [4]. Now more than one million organizations from more than 160 countries have applied the ISO 9001 standard requirements to their quality management systems. A total of 1106356 valid certificates were reported for ISO 9001 (including 80596 issued to the 2015 version) in 2016 [1].

ISO 9001 certification can have internal and external benefits. These benefits were well described by $[5,6]$. As internal benefits are identified - improved process and product quality and organizational effectiveness, increased involvement of people. Concerning external benefits, ISO 9001 contributes to a better customer service, complaints reduction and fewer complaints of suppliers [5;6].

The latest version ISO 9001:2015 brings some structural changes and changes in terms of the content. It includes a revised clause sequence and the adaptation of the revised quality management principles and of new concepts [2]. If ISO 9001:2008 emphasizes continual improvement and customer satisfaction, ISO 9001:2015 puts more focus on risk-based thinking [7]. The major changes are as follows:

- A high-level structure: the new structure is the most noticeable change to the standard. ISO 9001:2015 now follows the same overall structure as other ISO management system standards, making it easier for anyone using multiple management systems [1].

- The focus on risk-based thinking: it is a way of thinking that replaces preventive action and seeks to add some systematic evaluation of potential and actual issues with the aim of making processes more robust and capable [8]. More information on how to adapt to this risk-based thinking can be found in [9]. 
- Increased involvement of the leadership team: leadership replaced the previous edition concept of management responsibility, requiring top management to engage and support the QMS [10].

- A reinforced emphasis on the process approach and intended results with less emphasis on prescriptive requirements and on documentation [10].

- The consideration of change management and knowledge management has been introduced [10].

More information about the comparison of the changes between the ISO 9001:2008 and ISO 9001:2015 is given in [8; 10]. The comparison of clauses between both versions is presented in Table 1. While the previous version has 8 clauses, the new version has 10 clauses.

Table 1

The comparison of clauses between 2008 and 2015 versions of ISO 9001

\begin{tabular}{|l|l|}
\hline \multicolumn{1}{|c|}{ ISO 9001:2008 } & \multicolumn{1}{c|}{ ISO 9001:2015 } \\
\hline 1. Scope & 1. Scope \\
\hline 2. Normative References & 2. Normative References \\
\hline 3. Terms and Definitions & 3. Terms and Definitions \\
\hline 4. Quality Management System & 4. Organizational context \\
\hline 5. Management Responsibility & 5. Leadership \\
\hline 6. Resource Management & 6. Planning \\
\hline 7. Product Realizations & 7. Support \\
\hline \multirow{2}{*}{$\begin{array}{l}\text { 8. Measurement, Analysis and } \\
\text { Improvements }\end{array}$} & 8. Operation \\
\cline { 2 - 2 } & 9. Performance Evaluation \\
\cline { 2 - 2 } & 10. Improvement \\
\hline
\end{tabular}

An emphasis on risk-based thinking can contribute to eliminate complaints that are one of the biggest costs to be borne by the organization. An example of the importance of complaints in organization can be the Japanese airbag manufacturer Takata Corp. Its airbag inflators can explode with too much force, hurling shrapnel into drivers and passengers. The inflators are blamed for at least 16 deaths worldwide and more than 180 injuries. The problem touched off the biggest recall in the U.S. automotive history and the Japanese automotive parts company will pay a total of USD 1 billion in fines and restitution $[11 ; 12]$.

Complaints with suppliers are also very important because poor quality supplied products and services can have a huge negative impact on quality of the organization's production process and even worse - on its customers. ISO 9001:2015 requires the use of risk-based thinking to manage suppliers. The organization shall ensure that externally provided processes, products and services do not adversely affect the organization's ability to consistently deliver conforming products and services to its customers. The organization shall take into consideration the potential impact of the externally provided processes, products, and services on the organization's ability to consistently meet the customer and applicable statutory and regulatory requirements [2].

The aim of this paper is to: (i) analyse supplier claims in organization, (ii) identify the most problematic category of supplied products, and (iii) determine risk-based requirements for suppliers of this category with regard to the ISO 9001:2015.

\section{Materials and methods}

Organization XY was used as the case study in this paper. XY is located in the Czech Republic and is the molded plastic parts producer, including their decoration, assembling and final packaging process. XY is ISO 9001:2008 certified and will make the transition to the latest version of the standard in 2018.

The collected data was 2016 annual supplier claim report. This report presents data on XY's supplier claims in each category of the supplied products - cardboard, printed matter, plastic 
packaging, non-standard material, paints and granules. Claim frequency and claim costs were evaluated for each of these categories. Claim costs at XY are calculated according to (1). It is the sum of the material cost and manpower-hour costs including manual power hours and machine hours.

$$
C c=C_{M a t}+C_{M P H},
$$

where $C c$ - claim cost, EUR;

$C_{\text {Mat }}$-material cost, EUR;

$C_{M P H}$ - manpower-hour cost, EUR.

The collected data were analysed using the Pareto diagram to identify the most problematic supplied products in the XY claim process. The Pareto diagram is one of the seven basic quality tools and one of the most popular techniques for identifying the causes of quality problems. It is based on the Pareto principle, which states that $80 \%$ of the consequences stem from $20 \%$ of the causes. Formulated by the father of quality J. M. Juran and named after the famous Italian economist Vilfredo Pareto, this principle helps separate the "vital few" from the "useful many". This helps to focus on solving the right set of problems [13]. Pareto diagram is having bar graphs and line graphs, where individual items are represented by a bar graph in order of decreasing frequency and the cumulative total is shown by a line graph (Lorenzo curve) [14]. An example of the Pareto diagram is given in Fig. 1.

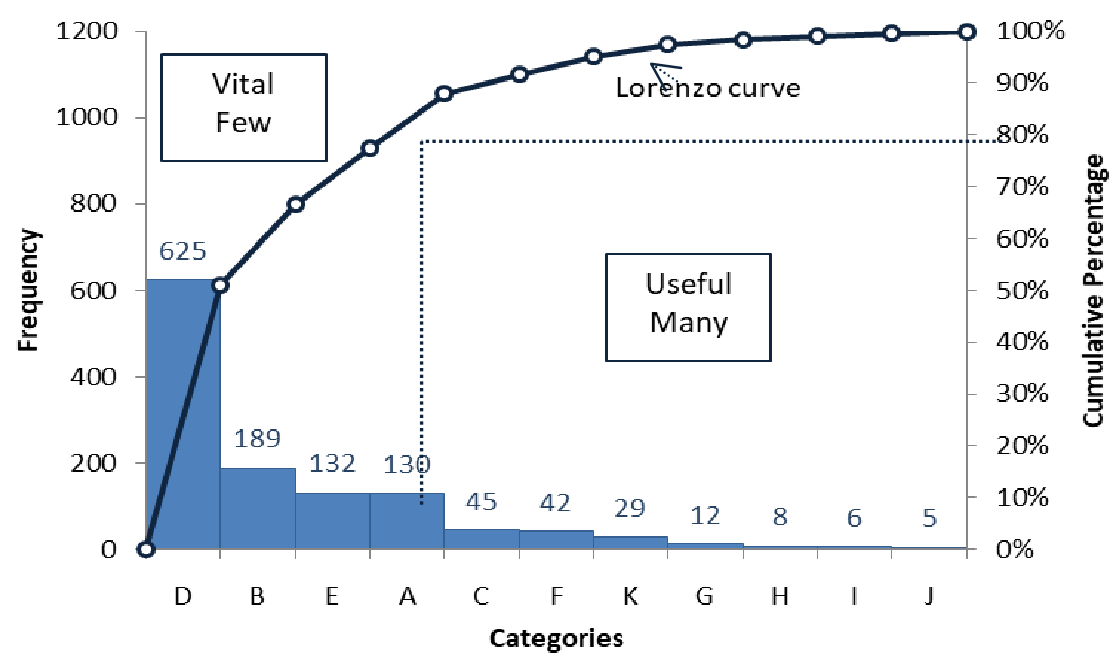

Fig. 1. Pareto diagram

\section{Results and discussion}

A total of 82 claims were made with total claim cost of EUR 15746 in 2016 at XY. Fig. 2 shows that cardboard and printed matter represent the most problematic categories of supplied products in terms of claim frequency.

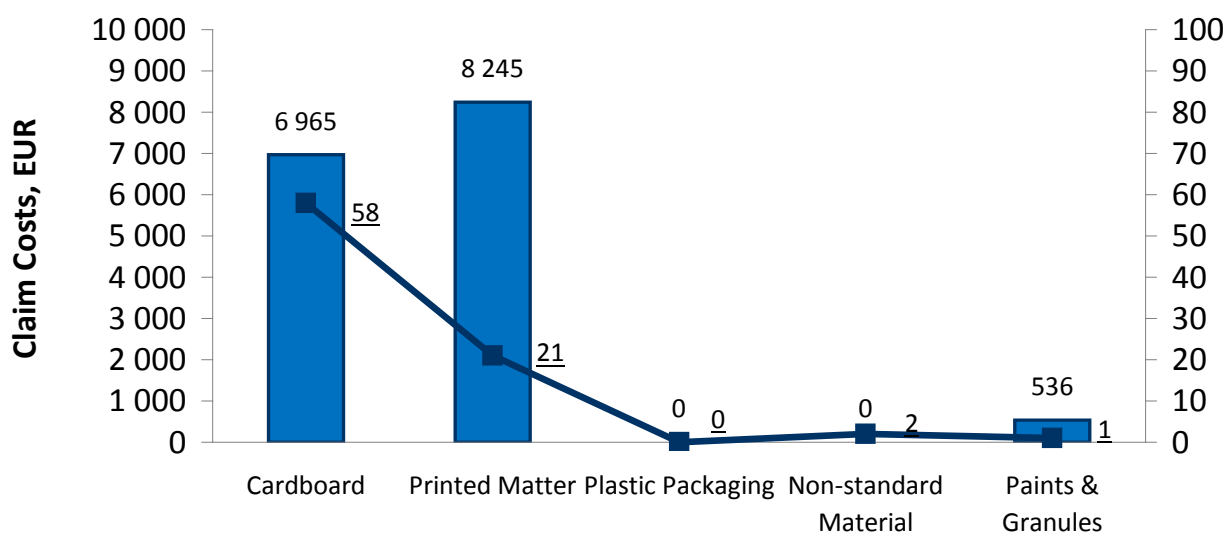

Fig. 2. Claim frequency and claim costs in each category of supplied products 
Conversely, claim frequency was minimal for plastic packaging, non-standard materials, paints and granules. Cardboard and printed matter are also the most problematic categories in terms of claim costs. Claim costs were low for paints and granules, and zero for plastic packaging and non-standard materials.

The same data are presented in Fig. 3 and Fig. 4. Pareto diagram of claim frequency can be found in Fig. 3. Pareto diagram of claim costs is given in Fig. 4. The criterion for identifying the "vital few" was chosen at level $70 \%$. Fig. 3 shows that the category of cardboard was identified as the "vital few" in terms of claims frequency. This category accounts for $71 \%$ of the total claims.
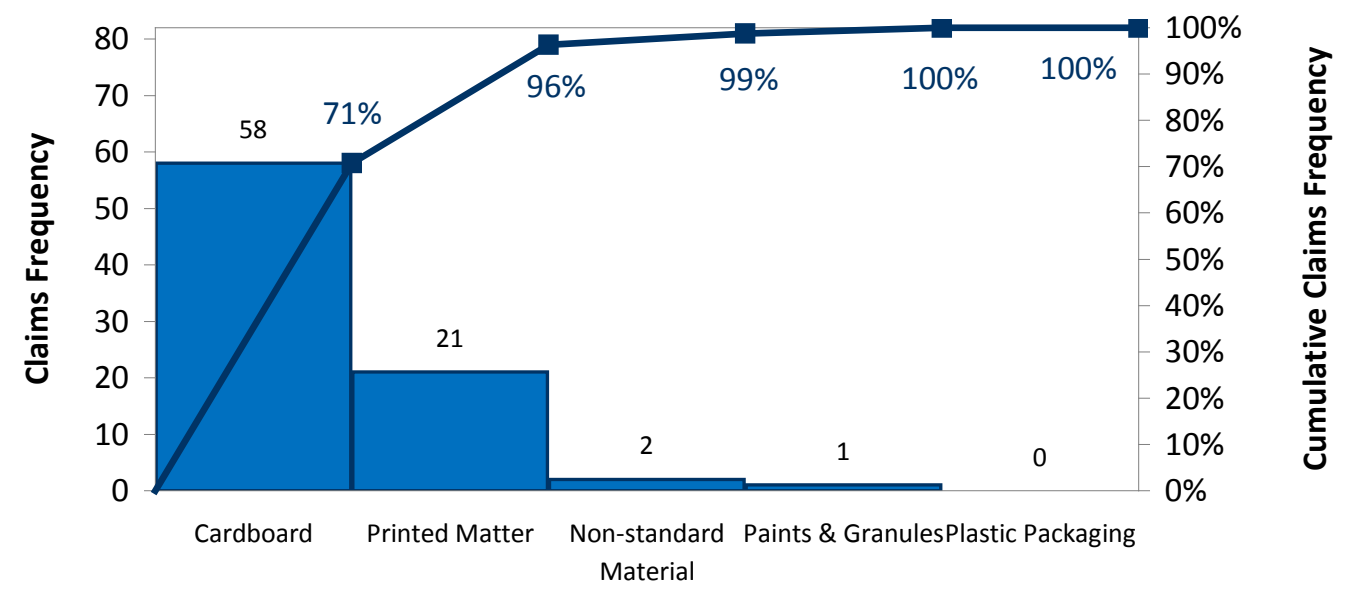

Fig. 3. Pareto diagram of claim frequency in each category of supplied products

Pareto diagram of claim costs (Fig. 4) takes into account the economic aspect and constitutes another approach to identifying the "vital few". Only one category of supplied products cannot be identified as the "vital few" in terms of claim costs. $70 \%$ of claim costs are caused by category of printed matter (52\% of total claim costs) and in part by category of cardboard (18\% of total claim costs). These two categories account for $97 \%$ of the total claim costs.

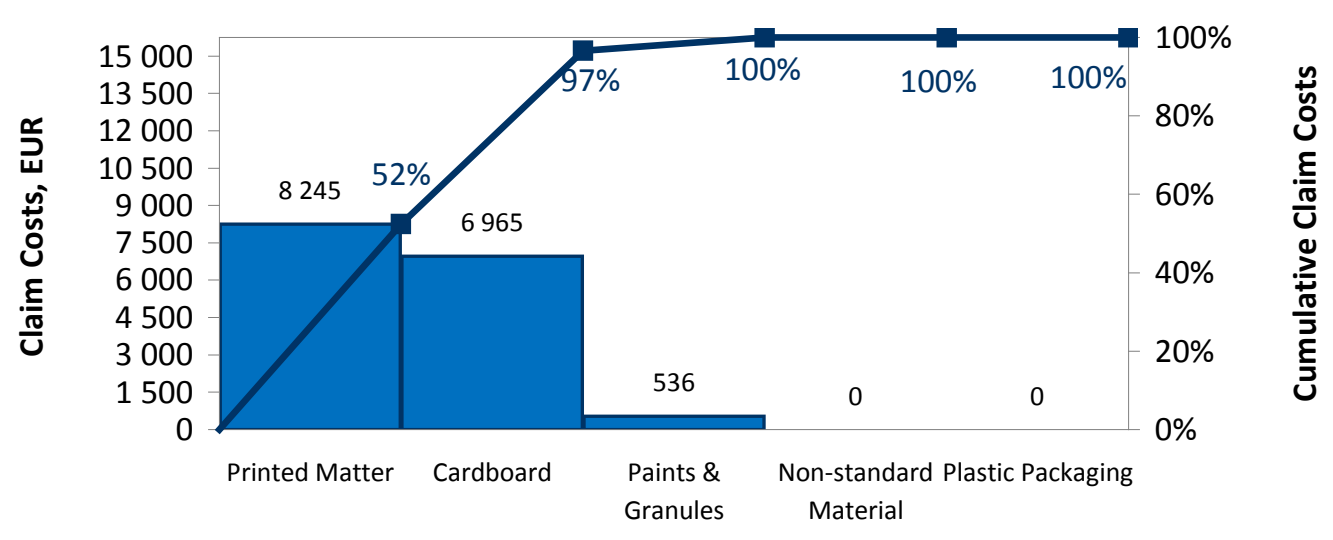

Fig. 4. Pareto diagram of claim costs in each category of supplied products

It follows from the above that cardboard was identified as the most problematic category of the supplied products in terms of claim frequency. Printed matter and partly cardboard was identified as the most problematic category of the supplied products in terms of claim costs.

One of the most significant changes in ISO 9001:2015 versus ISO 9001:2008 is the increased focus on risk-based thinking. The new version ISO 9001:2015 also requires the use of risk-based thinking to manage suppliers. Since XY will make the transition to this version, it should increase the requirements for selected suppliers of the most problematic products - for suppliers of cardboard and printed matter. These suppliers cause XY the most frequent and costly claims. They are at the same time the highest risk of XY's production. For example, the following categories can be used: 
- Strategic supplier - A supplier that provides a large number of products. There is currently no other supplier available to deliver the same kind of product.

- Supplier with poor rating - A supplier that has achieved a low level in regular Quality Supplier Evaluation.

- Supplier after big accident - A supplier that delivered nonconforming products and caused $\mathrm{XY}$ the necessity of recall and the impossibility of selling products (products blocked in distribution centres).

Table 2 shows example minimum requirements for selected supplier categories using a risk-based approach.

Table 2

Minimum risk-based supplier requirements

\begin{tabular}{|c|c|c|c|}
\hline \multirow{2}{*}{$\begin{array}{c}\text { Minimum } \\
\text { requirements }\end{array}$} & Strategic supplier & $\begin{array}{c}\text { Supplier with poor } \\
\text { rating }\end{array}$ & $\begin{array}{c}\text { Supplier after big } \\
\text { accident }\end{array}$ \\
\cline { 2 - 4 } QMS certification & ISO 9001 & ISO 9001 & ISO 9001 \\
\hline $\begin{array}{c}\text { Receiving } \\
\text { inspection }\end{array}$ & Permanent & Permanent & Temporary \\
\hline Supplier audit & Once a year & Once a quarter & After the accident \\
\hline FMEA & $\begin{array}{c}\text { Before conclusion of } \\
\text { the contract }\end{array}$ & Half-yearly & After the accident \\
\hline
\end{tabular}

XY should require these categories of suppliers to have their QMS based on the ISO 9001 standard to ensure that the supplied products consistently meet the quality requirements of $\mathrm{XY}$, and that the quality of the products is consistently improved. At the same time, XY should introduce receiving inspection for these categories of suppliers, such as sampling based on performance. A permanent receiving inspection should be implemented by strategic suppliers and suppliers with poor rating. Suppliers after big accident would have implemented a temporary receiving inspection. Its duration would depend on the verification of the corrective action. Supplier audits should be conducted by the XY audit team at different time intervals or after big accident, depending on the supplier category. It is also very important that all three categories of suppliers use the FMEA for risk analysis. XY should require strategic suppliers to use the FMEA before conclusion of the contract. Suppliers with poor rating should use the FMEA half-yearly and the remaining supplier category after the accident. More information about the FMEA as a step-by-step approach for identifying all possible causes of failure is given in [15].

\section{Conclusions}

Organizations that are currently registered to ISO 9001:2008 will have until September 2018 to pass over to the 2015 standard. One of the most significant changes in ISO 9001:2015 is the increased focus on risk-based thinking, which is also required to manage suppliers. This paper showed how this requirement could be met and the example of implementation in the organization XY. Analysis of supplier claims and use of minimum risk-based requirements for selected supplier categories of the most problematic products can lead to a significant reduction in claims and claim costs. The method used in this paper is very well applicable in the QMS and supply relationship management.

\section{References}

[1] International Organization for Standardization [online] [02.02.2018]. Available at: https://www.iso.org/home.html

[2] EN ISO 9001:2015 standard "Quality management systems - Requirements"

[3] What is ISO 9001:2015 - Quality Management Systems? [online] [02.02.2018]. Available at: http://asq.org/learn-about-quality/iso-9000/iso-9001-2015/ 
[4] Staněk M. Mezinárodní norma ISO 9001: pohled do historie a budoucnosti (International Standard ISO 9001: a look into the past and the future). Czech journal about quality: Perspektivy kvality, 2013, No 1. (In Czech).

[5] Casadesús M., Heras I., Ochoa C. The benefits of the implementation of ISO 9000 normative: Empirical research in the Spanish companies. Proceedings of International conference "Fifth world conference on production and operations management", 2000, Sevilla, Spain.

[6] Boiral O. ISO 9000 and organizational effectiveness: A systematic review. Quality Management Journal, vol. 19, 2012, pp. 16-37.

[7] Sari Y., Wibisono E., Wahyudi R.D., Lio Y. From ISO 9001:2008 to ISO 9001:2015: Significant changes and their impacts to aspiring organizations. Proceedings of "International Conference on Informatics, Technology and Engineering", August 24-25, 2017, Univ Surabaya, Indonesia.

[8] Fonseca L. From Quality gurus and TQM to ISO 9001:2015: a review of several quality paths. International Journal for Quality Research, vol. 9, 2015, pp. 167-180.

[9] Ezrahovich A.Y., Vladimirtsev A.V., Livshitz I.I., Lontsikh P.A., Karaseva V.A. Risk-based thinking of ISO 9001:2015 - The new methods, approaches and tools of risk management. Proceedings of International conference "Quality Management, Transport and Information Security, Information Technologies", October 26, 2017, St. Petersburg, Russian Federation, pp. 506-511.

[10] Fonseca L., Domingues J.P. ISO 9001:2015 edition- management, quality and value. International Journal for Quality Research, vol. 11, 2016, pp. 149-158.

[11] Airbag manufacturer Takata Corp. pleads guilty to fraud, to pay \$1-billion penalty [online] [28.02.2018]. Available at: https://www.thestar.com/business/2017/02/27/attorneys-say-fiveautomakers-knew-takata-airbags-were-dangerous.html

[12] Takata to plead guilty in air bag case [online] [28.02.2018]. Available at: http://www.dw.com/en/takata-to-plead-guilty-in-air-bag-case/a-37739408

[13] Nenadál J., Noskievičová D., Petř́́ková R., Plura J., Tošenovský J. Moderní management jakosti: principy, postupy, metody (Modern quality management: principles, procedures, methods). Praha: Management Press, 2008. (In Czech).

[14] Veber J., Hůlová M., Kořánová H., Plášková A. Řízení jakosti a ochrana spotřebitele (Quality mangement and consumer protection). Praha: Grada Publishing, 2007. (In Czech).

[15] Juran J.M., Blanton Godfrey A. Juran's quality handbook. Fifth edition. New York: McGraw-Hill, 2000 